Bolm Inst. oceanogr., S Paulo, 33(2):99-104, 1985

\title{
ESTIMATION OF ANNUAL HEAT FLUX BALANCE AT THE SEA SURFACE FROM SST (NOAA-SATELLITE) AND SHIPS DRIFT DATA OFF SOUTHEAST BRAZIL
}

\author{
Yoshimine IKEDA ${ }^{1}$ \& Merritt Raymond STEVENSON ${ }^{2}$
}

1 Instituto Oceanogräfico da Universidade de São Paulo (Caixa Postal 9075, 01000 São Paulo, SP)

2 Instituto de Pesquisas Espaciais (Caixa Postal 515, SP) 12200 São José dos Campos, SP

\section{Synopsis}

The objective of this work is to study the possibility of estimating the heat flux balance at the sea surface from GOSSTCOMP (Global Ocean Sea Surface Temperature Computation) developed by NOAA/NESS, USA, and sea surface current data based from ships drift information obtained from Pilot Charts, published by the Diretoria de Hidrografia e Navegasão (DHN, Brazilian Navy). The annual mean value of the heat flux balance at the sea surface off southeast Brazil for 1977, is estimated from data on the balance between the heat transported by the currents and that transported by eddy diffusion for each volume defined as $2^{\circ} x 2^{\circ}$ (Lat. $x$ Long.) square with a constant depth equivalent to an oceanic mixed layer, $100 \mathrm{~m}$ thick. Results show several oceanic areas where there are net flows of heat from atmosphere towards the sea surface. In front of Rio de Janeiro the heat flow was dowroward and up to $70 \mathrm{ly}$ doy ${ }^{-1}$ and is probably related to the upwelling phenomenon normally occurring in that area. Another coastal area between Lat. $25^{\circ} \mathrm{S}$ to $28^{\circ} \mathrm{S}$ indicated an dowroward flow up to $50 \mathrm{ly}$ day ${ }^{-1}$; and for an area south of Lat. $27^{\circ} \mathrm{S}$, Long. $040^{\circ} \mathrm{W}-048^{\circ} \mathrm{W}$ an downward flow up to $200 \mathrm{ly}_{\mathrm{y}}$ day ${ }^{-1}$, where the transfer was probably due to the cold water of a nortward flux from the Falkland (Malvinas) Current. Results also show several oceanic areas where net flows of heat (of about $-100 \mathrm{ly}_{\mathrm{y}} \mathrm{day} \mathrm{y}^{-1}$ ) were toward the atmosphere. In the oceanic areas Lat. $19^{\circ} \mathrm{S}-23^{\circ} \mathrm{S}$ and Lat. $24^{\circ} \mathrm{S}-30^{\circ} \mathrm{S}$, the flows were probably due to the warm water of a southward flux of the Brazil Current. The resulting fluxes from the warm waters of the Brazil Current when compared with those from warm waters of the Gulf Stream and Kuroshio, indicate that the Gulf Stream carries about 3.3 times and the Kuroshio 1.7 times more heat than the Brazil Current. These values agree with those of data available on the heat fluxes of the above mentioned Currents calculated by different methods (Budyko, 2974).

Descriptors: Heat balance, Heat transfer, Brazil Current, Falkland (Malvinas) Current, Remote sensing, NOAA satellite, Upwelling, Ocean currents, Eddy diffusion, Mixed layers, Southeast Brazilian coast.

Descritores: Balanço de calor, Transferência de calor, Corrente do Brasil, Corrente de Falkland (Malvinas), Sensoriamento remoto, Satëlite NOAA, Ressurgência, Correntes, Difusão turbulenta, Camadas de mistura, Costa sudesteBrasil.

\section{Introduction}

The objective of this study is to evaluate an alternate method to determine the heat flux balance at the sea surface from remote sensing measurements. Quantitative estimates of the heat balance have been obtained for the tropical Atlantic and Eastern Pacific by Hastenrath \& Lamb (1978), based on surface meteorological observations made by ships during 1911-1970. Also, Publ. n. 629 do Inst. oceanogr. da Usp.
Privett (1960) estimated the change of energy between the atmosphere and the oceans of the Southern Hemisphere using surface observations recorded aboard selected British ships.

The present work was based on a paper by Oort \& Vonder Haar (1976) using satellite data of the top of the atmosphere for the Northern Hemisphere. Our paper indicates that the same approach applied to the region off Brazil shown in Figure 1 may also give satisfactory results. 


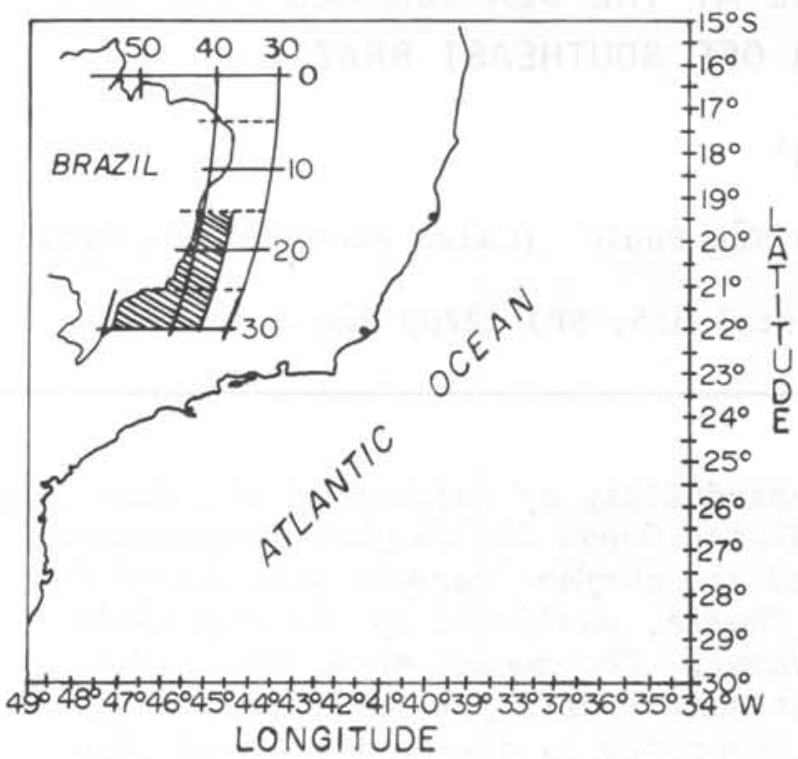

Fig. 1. Study area.

\section{Material and methods}

The sea surface temperature (SST)

data used in this study were produced by the GOSSTCOMP satellite program developed by NOAA/NESS, USA and are given as SST values on a $1 / 2^{\circ}$ by $1 / 2^{\circ}$ grid. Details on their reduction are given by Ikeda \& Stevenson (1978).

The selection of data from the year 1977 is related to a paper published recently by Strong \& Pritchard (1980). The authors compared SST anomalies using GOSSTCOMP data and National Marine Fisheries Service vessel's data over the North Pacific Ocean, and the smallest differences were obtained with data covering the winter of 1977-78.

The monthly mean sea surface current values used are taken from the Pilot Charts, published by Diretoria de Hidrografia e Navegação (Brasil, 1974). The data cover a period of 21 years, from 1951 to 1972 .

To determine the terms related to the heat flux balance at the sea surface from SST, ocean currents, eddy diffusion and the mixed layer, our starting point is the mathematical expression presented by Smirnova (1970).

We have

$\rho c p \int_{0}^{H} \frac{\partial T}{\partial t} d z=\rho c_{p} \overline{K \nabla^{2}} T H-\rho c_{p}\left(\bar{u} \frac{\partial \bar{T}}{\partial x}+\right.$

$$
\left.+\bar{v} \frac{\partial \bar{T}}{\partial y}\right) H+Q\left[1 y s^{-1}\right]
$$

where: $\underline{\mathrm{T}}$ - sea surface temperatura $\left({ }^{\circ} \mathrm{C}\right)$

$\mathrm{u}, \bar{v}$ - current velocity components $\left(\mathrm{cm} \mathrm{s}^{-1}\right)$

K - horizontal eddy diffusion coefficient $\left(\mathrm{cm}^{2} \mathrm{~s}^{-1}\right)$

$\mathrm{H}$ - mixed layer thickness (cm)

Q - heat flux balance at sea surface $\left(1 \mathrm{y} \mathrm{s}^{-1}\right)$.

$\rho c_{p} \equiv 1.0\left[\mathrm{cal}{ }^{\circ} \mathrm{C}^{-1} \mathrm{~cm}^{-3}\right]$

$\int_{0}^{\mathrm{H}} \frac{\partial \mathrm{T}}{\partial t} \mathrm{dz}=\mathrm{Q}_{\mathrm{A}}$ (heat storage)

$\left(\bar{u} \frac{\partial \bar{T}}{\partial x}+\bar{v} \frac{\partial \bar{T}}{\partial y}\right) H=Q_{c}$ (heat transported by current)

$\overline{\mathrm{K} \nabla^{2}} \mathrm{TH}=\mathrm{Q}_{\mathrm{d}}$ (heat transported by eddy diffusion)

Chossing the finite difference method to the partial derivative (Roache, 1972), equation (3) and (4) become:

$$
\begin{aligned}
Q_{c}= & {\left[\bar{u} \frac{\bar{T}_{j, i+1}-\bar{T}_{j, i-1}}{2 \Delta x}+\right.} \\
& \left.+\bar{v} \frac{\bar{T}_{i, j+1}-\bar{T}_{i, j-1}}{2 \Delta y}\right] H\left[1 y^{-1}\right]
\end{aligned}
$$

$$
\begin{aligned}
Q_{d}= & K\left[\frac{\overline{\mathrm{T}}_{j, i+1}+\overline{\mathrm{T}}_{j, i-1}-2 \overline{\mathrm{T}}_{i, j}}{\Delta \mathrm{x}^{2}}+\right. \\
& \left.+\frac{\mathrm{T}_{i, j+1}+\mathrm{T}_{i, j-1}-2 \mathrm{~T}_{i, j}}{\Delta \mathrm{x}^{2}}\right]
\end{aligned}
$$


The following assumptions were made for the annual mean value calculation:

1) $\overline{\mathrm{u}}=\overline{\mathrm{v}} \cong 50 \mathrm{~cm} \mathrm{~s}^{-1}$ and $\mathrm{X}=\mathrm{Y} \cong 1,200 \mathrm{~km}$

2) eddy diffusion coefficient $K$ is considered constant and equal to $10^{7} \mathrm{~cm}^{2} \mathrm{~s}^{-1}$;

3) depth $\mathrm{H}$ is the mixed layer tickness, constant and equal to $100 \mathrm{~m}$, Navrotskiy (1970);

4) mean current velocity is constant and mean SST is the temperature in the surface mixed layer

5) no vertical heat flux exchange occurs between the surface mixed layer

(H) and the lower column.

After calculating $Q_{c}$ and $Q_{d}$ for each volume of a $2^{\circ} \times 2^{\circ}$ (Lat. $\times$ Long.) square based on SST values at $1^{\circ}$ geographic interval and a constant depth equivalent to the oceanic mixed layer (100 m thick) and adopting a control volume of $2^{\circ} \times 2^{\circ}$ (Lat. x Long.) area, it is possible to find the sea surface heat flux balance, shown in Figure 2.

Positive values (+) indicate a gain in heat and negative values (-) a loss of heat across the face of the volume as shown in Figure 2.

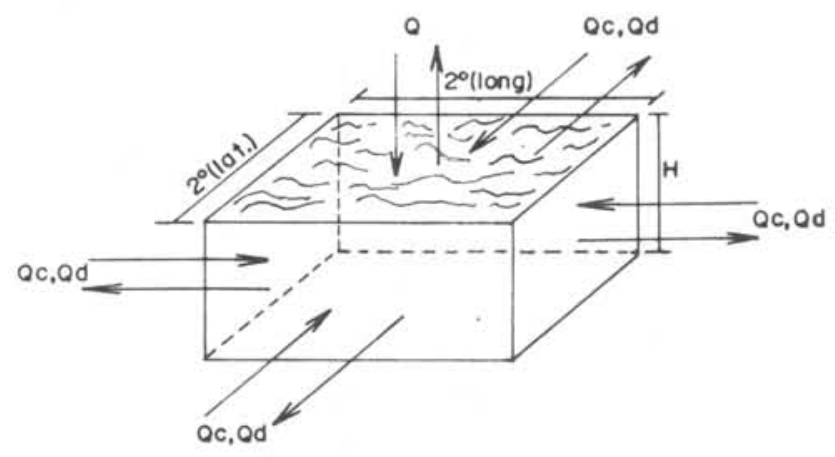

Fig. 2. Control volume.

\section{Results}

A strong displacement of the isotherms in the area comprised between Lat. $23^{\circ} \mathrm{S}-$ $28^{\circ} \mathrm{S}$ and Long. $041^{\circ}-047^{\circ} \mathrm{W}$, is observed in Figure 3 were the isotherms are represented at each $0.5^{\circ} \mathrm{C}$ interval of SST. The NOAA satellite temperature data used are plotted at each $0.5^{\circ}$ (Lat. x Long.) interval and correspond to the annual mean value obtained from weekly satellite data covering the year 1977.

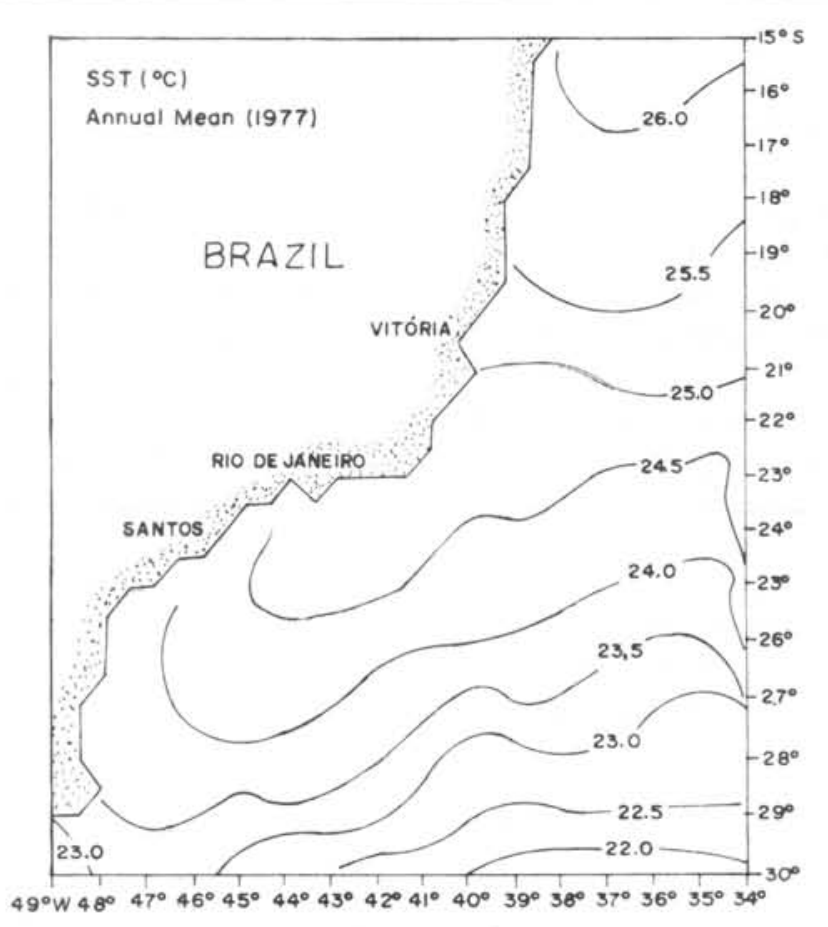

Fig. 3. SST annual mean value (1977) from NOAA satellite data.

The annual mean scalar velocity estimated from monthly mean velocity data (Pilot Charts) is shown in Figure 4. The speed varied from $10 \mathrm{~cm} \mathrm{~s}^{-1}$ to $30 \mathrm{~cm} \mathrm{~s}^{-1}$ and the corresponding isoline $(>30 \mathrm{~cm}$ $\mathrm{s}^{-1}$ ) followed the coastline.

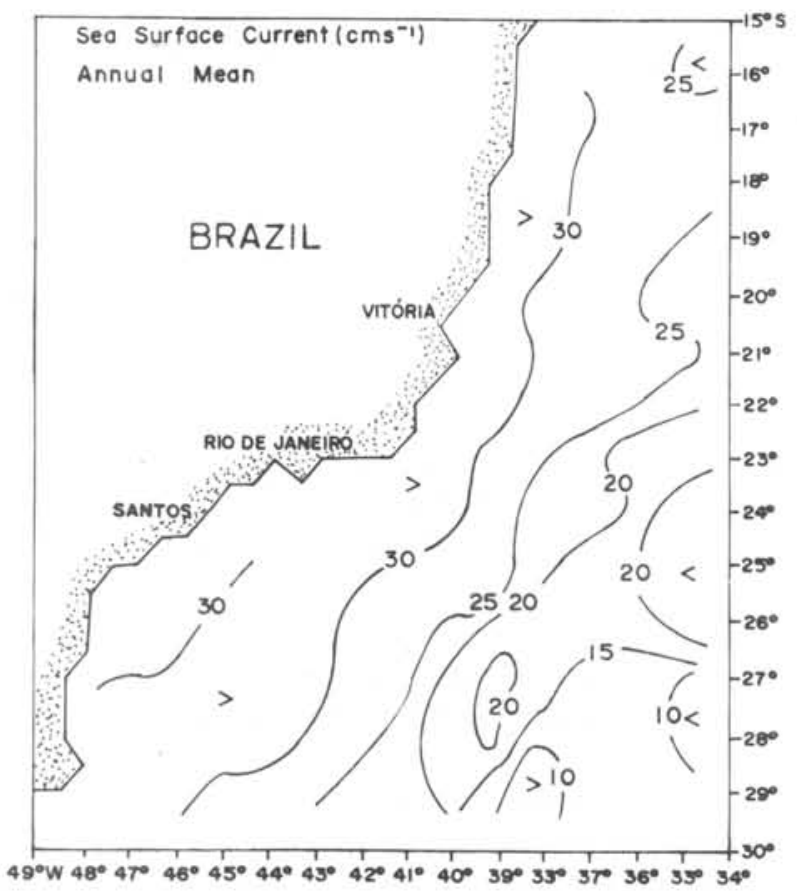

Fig. 4. Annual mean sea surface currents data from Pilot Charts. 
The annual mean (vector) velocity field based on the same ships drift data is shown in Figure 5. The mean vector field clearly shows the presence of the Brazil Current in the litoral zone. An apparent decrease in the width of the Brazil Current is evident east of Cabo Frio near $23^{\circ} \mathrm{S}, 37^{\circ} \mathrm{W}$. The surface water extending further eastward and to the south is a part of a large scale counter clockwise circulation and apparently is not a part of the litoral circulation.

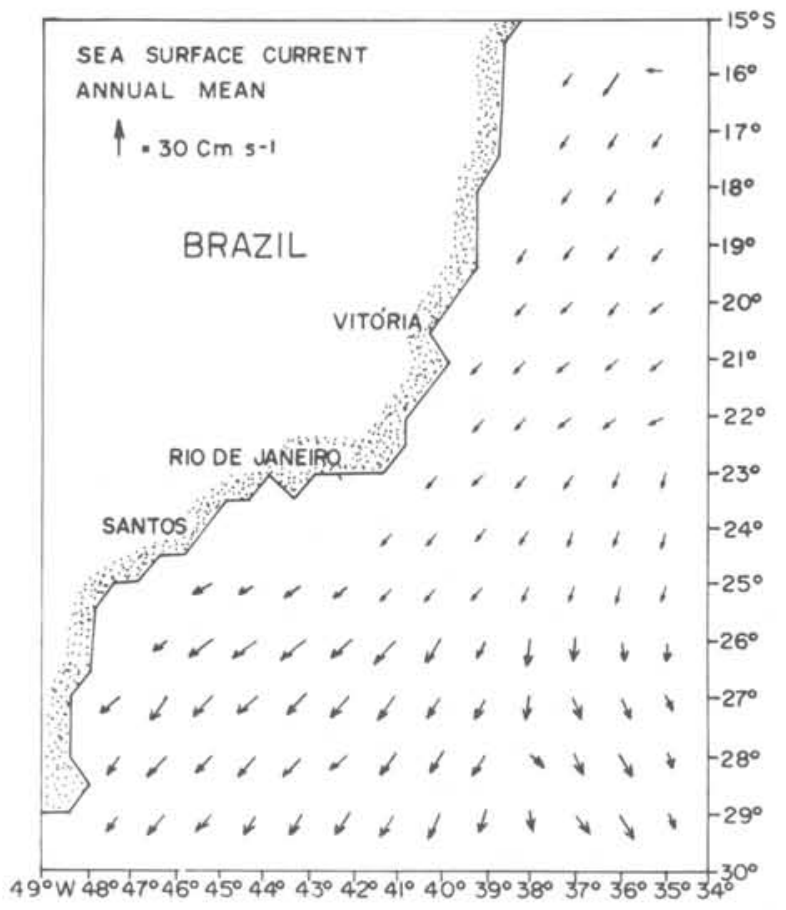

Fig. 5. Annual mean sea surface current.

The annual vertical mean heat flux in the mixed layer due to the ocean currents was calculated using equation (5) and is plotted in Figure 6 . Heat gain of up to $1001 \mathrm{y} \mathrm{day}{ }^{-1}$ was observed in three areas bounded by Lat. $26^{\circ} \mathrm{S}-28^{\circ} \mathrm{S}$ and heat loss of up to $-2001 \mathrm{y} \mathrm{day}^{-1}$ at Lat. $28^{\circ} \mathrm{S}$.

The annual vertical mean heat flux in the mixed layer contributed by eddy diffusion was calculated from equation 6 and plotted in Figure 7. A heat gain of up to $601 \mathrm{y} \mathrm{day}^{-1}$ was observed in two areas located between Lat. $26^{\circ} \mathrm{S}$ and $28^{\circ} \mathrm{S}$; a heat loss was found in front of Rio de Janeiro at a rate of up to $-801 \mathrm{y} \mathrm{day}^{-1}$.

The sum of terms of heat transfer due to ocean currents and eddy diffusion represents the heat flux balance at the
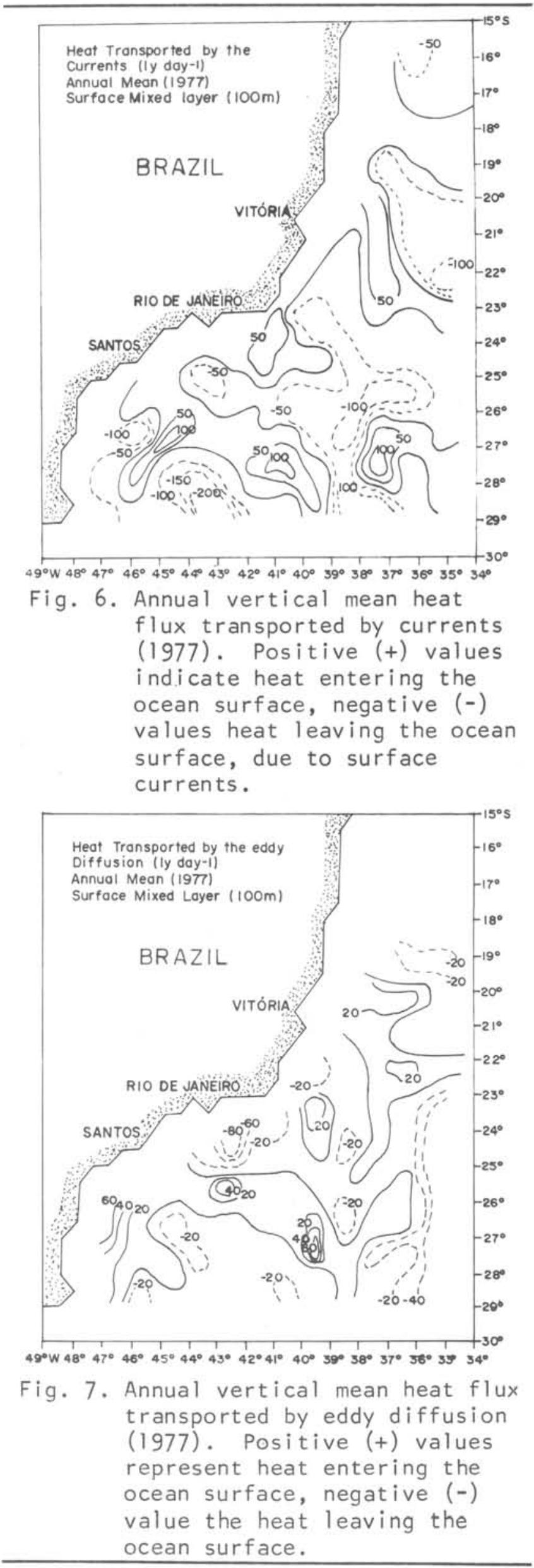
sea surface. The results (Fig. 8) show the sea surface annual mean gain in heat flux in front of Rio de Janeiro to approach $701 \mathrm{y} \mathrm{day}{ }^{-1}$; in front of the coast between Lat. $26^{\circ}-28^{\circ} \mathrm{S}$ up to $50 \mathrm{ly}$ $\mathrm{day}^{-1}$, and a loss of heat between these areas of up to $-1001 \mathrm{y} \mathrm{day}^{-1}$.

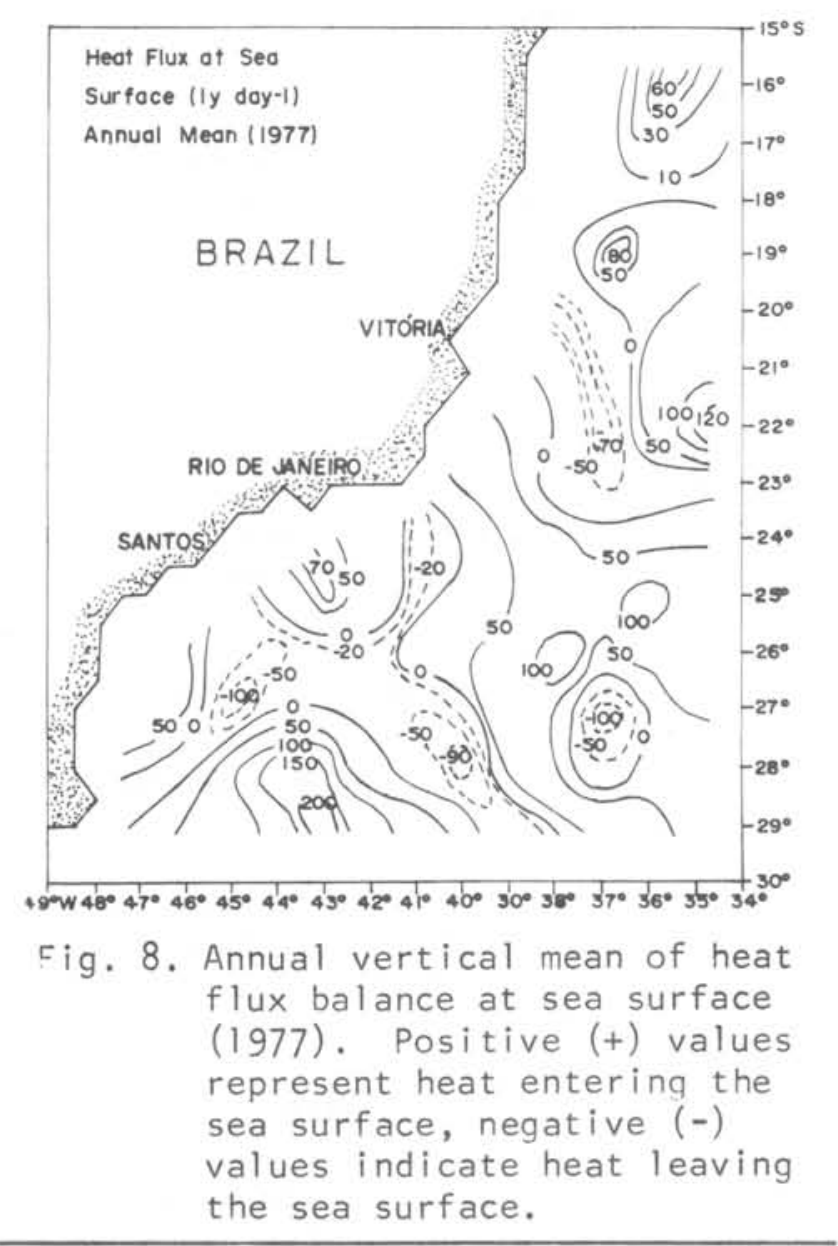

\section{Discussion}

The southward displacement of the isotherms near the coast (Fig. 3) may indicate the influence of the Brazil Current, characterized by warm water with a southward flux shown in Figures 4 and 5, through the velocity field along the coast line $\left(>30 \mathrm{~cm} \mathrm{~s}^{-1}\right)$. The heat transported by this current along the coastline is verified in Figure 6, with the mean annual value of heat gain reaching up to $1001 \mathrm{y} \mathrm{day}{ }^{-1}$.

Budyko (1974) refers to the great importance of the gain or loss of heat balance of the oceans, resulting from horizontal heat exchange, due mainly to the activity of ocean currents. Such a relationship is observed, for example, for warm currents such as the Gulf Stream and Kuroshio 1.7 times greater than that transported by the Brazil
Current. In cold waters such as those of the California Current and of the Benguela Current, both with heat losses of up to - $1101 \mathrm{y} \mathrm{day}{ }^{-1}$, the data available indicate that the outgo of heat of the California Current and Benguela Current is 1.8 times smaller than that of the Falkland (Malvinas) Current.

Another fact to be noted is the mean annual value up - $80 \mathrm{ly} \mathrm{day}^{-1}$ of heat loss by eddy diffusion (Fig. 7), in front of Rio de Janeiro, probably due to the upwelling phenomenon occurring in the area.

Privett (1960) estimated values of mean annual heat balance in the southern Atlantic at $-1521 \mathrm{y} \mathrm{day-1}$ to $17 \mathrm{ly} \mathrm{day}^{-1}$; Budyko (1974) at $-801 \mathrm{y} \mathrm{day}^{-1}$ to $101 \mathrm{y}$ day $^{-1}$; Hastenrath \& Lamb (1978) found -90 $1 \mathrm{y} \mathrm{day}^{-1}$ to $201 \mathrm{y} \mathrm{day}^{-1}$ and our results (Fig. 8) obtained - $1001 \mathrm{y} \mathrm{day}^{-1}$ to 200 $1 y \mathrm{day}^{-1}$. Our calculations show significant differences, only for heat gain, occurring south of Lat. $27^{\circ} \mathrm{S}$. This may be due to insufficient meteorological data available for this area to the above mentioned studies.

To verify seasonal influence monthly mean heat flux at sea surface were drawed. These results show (Fig. 9) the sea surface gain in heat flux during six months (Jan, Feb, Mar, Oct, Nov and Dec) and lost during another six months (Apr, May, Jun, Jul, Aug and Sept). The

Heat flux at sea surface

Monthly mean (1977)

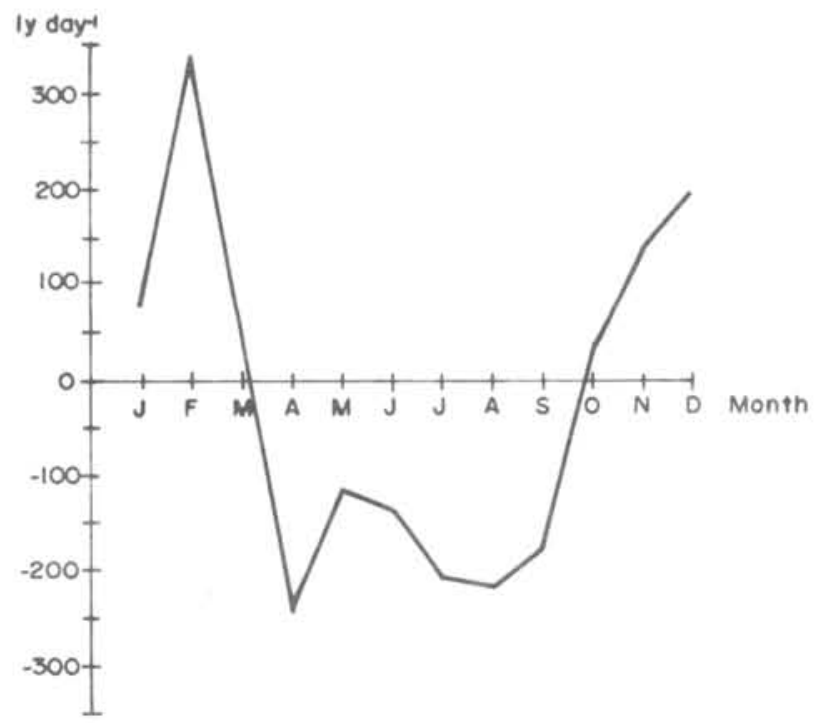

Fig. 9. Heat flux at sea surface for the study area. 
decrease in lost heat flux during May and June probably are due to the cold water influenced by the Falkland/Malvinas Current and upwelling phenomena (this year occurred "El Niño" in the Pacific Ocean).

The distribution of isolines (Fig. 8) in some oceanic regions does not fully correspond to the location of the main regions of warm and cold water currents. This fact is partially explained by the values shown in Figure 8 , which represent just one of the consequences of this transfer, rather than a direct heat transport by the ocean currents.

\section{Conclusions}

The study shows that it is possible to estimate the heat flux balance at the sea surface over a large area, using NOAA satellite data and information about currents available from Pilot Charts.

The mean annual values obtained from this study and the patterns of the heat flux balance at the sea surface are strongly influenced by the warm waters of the Brazil Current and the cold waters of the Flakland (Malvinas) Current.

In the area of Rio de Janeiro, the presence of cold water is probably due to local upwelling and has a strong influence on the heat flux balance at the sea surface.

The annual mean of the heat flux (Fig. 8) shows that the magnitude of heat gain at the sea surface in the study area is higher than the heat loss.

In the region under observation, it was verified that the areas with a heat gain are larger than those where a loss of heat occurs.

\section{Acknowledgements}

The basic GosSTCOMP data were provided at weekly intervals, courtesy of NESS/ NOAA. The preparation of this report was supported by the Integrated Project for the Use and Rational Exploitation of the Environment, subproject, Marine Fisheries (FINEP) and Oceanographic Institute of São Paulo University, Brazil. Support for the second author was provided through CNPq/INPE FINEP Contract no B/54/81/ 042/00/00 and is acknowledged with appreciation. Our thanks are due to
MSc. Nuno Pereira Filho for the guidance in using computer programmes; to Dr Afrânio Rubens de Mesquita, Drs Sérgio Romano Signorini and Affonso da Silveira Mascarenhas $\mathrm{Jr}$, who made very helpful comments, to Mrs Maria Cecilia Catunda, for the revision of the English manuscript and Osmar Mariano Pires de Campos, for the drawings.

\section{References}

BRASIL, Ministērio da Marinha, DHN. 1974. Atlas de Cartas Piloto n? 14.200 .

BUDYKO, M. I. 1974. Climate and life. New York, Academic Press.

HASTENRATH, S. \& LAMB, P. J. 1978. Heat budge at 1 as of the tropical Atlantic and eastern Pacific Oceans. Madison, University of Wisconsin Press, 90p.

IKEDA, Y. \& STEVENSON, M. 1978. Time series of NOAA-4 sea surface temperature (SST) data. Remote sens. Environm., 7:349-360.

NAVROTSKIY, V. V. 1970. Statistics of the thermocline in the Atlantic Ocean. Oceanol. Acad. Sci. USSR, 11(4):517524 .

OORT, H. A. \& VONDER HAAR, T. H. 1976. On the observed annual cycle in the ocean-atmosphere heat balance over the Northern Hemisphere. J. phys. Oceanogr., 6(6):781-800.

PRIVETT, D. W. 1960. The exchange of energy between the atmosphere and the oceans of the Southern Hemisphere. Geophys. Mem., Lond., 13(104):1-61.

ROACHE, P. J. 1972. Computacional fluid dynamics. Alburquerque, Hermosa Pub1., 446p.

SMIRNOVA, A. I. 1970. Heat transfer by currents in the North Atlantic. Oceano1. Acad. Sci. USSR, 10(1):21-27.

STRONG, A. E. \& PRITCHARD, J. A. 1980. Regular monthly mean temperatures of earth's oceans from satellites. Bull. Am. Meteorol. Soc., 61 (6):553-559.

(Received 03-0ct-1983; accepted 23-Aug-1985) 